possible causes underlying them. The following are suggested :

(a) Variation in the locality of the spawning ground. In the case of the haddock, the main centre of spawning activity may vary in position by so much as almost $2^{\circ}$ of latitude. The effect of this movement of location is probably mainly an indirect one in that it influences the primary distribution of the eggs and fry.

(b) The numbers and average age of the spawning fish. The spawning shoals are always composed ehiefly of haddock from three to six years old, and therefore include a series of broods differing in themselves in initial numerical strength. As there is an appreciable difference between the spawning locations assumed by younger and older haddock, the outcome may well be that the eggs and fry resulting from the spawning of younger fish predominating in one year will drift in quite a different set of currents from those resulting from the spawning of older fish predominating in another year.

(c) Early food supply. There is reason to suppose that the food requirements of the earlier (fry) stages are highly specialised, and that the necessary food organisms fall short of the demand to a greater or less extent in certain years. This, possibly, is the main cause underlying the not unusual wholesale failure of a brood.

Finally, as a result of careful analysis of the existing composition of the North Sea haddock, Dr. Thomson has been able to formulate the following tentative estimate of the immediate (1929) outlook for the fishery. "As the 1927 brood has proved to be almost a failure, catches may be expected to dwindle below the normal from the late autumn until well into next year (1930). About August of 1930 there should be a marked increase in the catches owing to the upgrowth of the very successful 1928 brood. In 1931 still greater catches should accrue. This is as far as can be seen ahead, for by the autumn of that year the influence of the 1928 brood will be waning and the next determining factor will be the quality, as yet unknown, of the brood of 1929. Estimations are therefore necessarily restricted to about two years ahead in the case of the southern portion of the North Sea. If these general anticipations prove correct an attempt should certainly be made to form seasonal or even monthly forecasts for the main fishing grounds."

Dr. Johan Hjort, in a brief survey of the methods and general principles underlying investigations into fluctuations in the stock of fishes, lays great stress upon the importance of the work. He suggests the setting up of an international biological organisation for the regular observation of age-distribution in the stock of our food fishes and of the relative-in time perhaps even the absolute - numerical strengths of the year-classes. Such a biological service, dealing conjointly with both biological statistics and a biochemical study of the fluctuating conditions in the sea, would in due course throw new light on many problems, and render possible a trustworthy fishery prediction service.

\title{
Linnæus and the Production of Artificial Pearls.
}

I INN EUS was a great naturalist, but one gathers 11 a fresh idea of his manifold interests in Nature from the series of articles in Svenska Linné-Sällskapets Arsskrift, Ârg. 13, 1930. One of the most curious of these papers, by Gustaf Drake, recounts an incursion of Linnæus into the artificial pearl trade. In the course of his journey through Lapland, Linnæus paid a visit to a pearl-fishery, where the pearls were derived from fresh-water mussels. Knowing that various species of mollusea, both fresh-water and marine, could produce pearls, he formed the opinion that theoretically they could be formed by any shell, and turned his attention to their artificial production. He carried out several successful experiments, and Beckmann records that in 1765 he was shown by Linnæus himself four or five real pearls lying within the shells of $M y a$ margaritifera, with the proud announcement: "hos uniones ipse artificio meo arcano confeci." Before this time, however, word had got abroad of Linnæus's pearlmaking secret, and in 1761-62 he was induced to demonstrate his method to Parliament. As a reward he was allowed the right of nominating his own successor, and chose his only son. But he also had a tempting offer from a private person for the monopoly of his pearl-producing method, though he did not accept it.

It is interesting to recall that the manuscripts explaining the pearl-producing method of Linnæus came into the hands of Sir James Smith and to repeat the latter's strong opinion regarding the exploitation of such scientific researches, conveyed in a letter dated Nov. 28, 1821: "The only pearls I ever expected from the possession of your illustrious countryman's literary treasures are pearls of science, in which I have not been disappointed. I am contented with these, and am happy that Sweden appears satisfied with what I have done for the honour of Linnæus and for the science to which I have devoted myself, in humble imitation of that great man. I believe
I am possessed of manuscripts of his own explaining the secret of producing pearls. I have also in his own cabinet of shells specimens of pearls so produced, and of mussel shells in various states upon which experiments have been made. I have no intention of carrying out the scheme-still less of paying $£ 500$ for any further information, nor, in short, of entering at all on the subject, for which I have no leisure." Can any of our readers say whether the experimental shells referred to are still in existence, and if so, whether the public has ever had an opportunity of seeing so interesting an exhibit ?

The natural philosophy of Linnæus is the subject of another very interesting contribution in the same Arsskrift. The Rev. Dr. Elis Malmeström considers that although Linnæus scarcely formulated a natural philosophy of his own, his ideas moved in the direction of such a philosophy, and in the preface and introductions to his various works he often indicated the direction of his thoughts about the universe, creation, life and its purpose. Three transitional stages of development are observable. In the first, ending about 1735, Linnæus expressed in the first edition of "Systema Naturae" a static idea of Nature which he had gathered from the Bible and especially from the creation myths of the Old Testament. Such an idea is presupposed by the whole of his systematic work, and he never really forsook it. The second period, up to about 1750 , saw an endeavour to unify the discrepancies which appeared to be increasing between creed and science. The fixity of species seemed less assured than formerly, but Linnæus stood firm against materialism, and adopted the physico-theology of his day. The third period, from 1750 until his death, marked a strong drift toward theodicy and a teleological view of Nature. He now adopted a natural theology, in which everything worked for the glory of God. Behind his thoughts on natural philosophy lay a religious craving for harmony. 